\title{
Forsvar med forbehold
}

\section{Henrik Larsen}

\author{
Det danske forsvarsforbehold var i 1990'erne af \\ begrænset rækkevidde, men efter Saint Malo i \\ 1998, hvor UK og Frankrig enedes om at bruge \\ EU som udgangspunkt for en europæisk militær \\ kapacitet, er udviklingen gået op i et højere gear
}

Denne artikel vil først kigge på betydningen af det danske forsvarsforbehold siden 1993. Dernæst behandles konsekvenserne af forbeholdet for Danmarks indflydelse i og uden for EU. Til slut diskuteres relevansen af en afstemning om forsvarsforbeholdet i lyset af annonceringen af afstemninger om forbeholdene i regeringens handlingsprogram fra november 2007

Det danske forsvarsforbehold inden for EU var i 1990'erne af relativt begrænset rækkevidde, selv om det ledte til, at Danmark otte gange holdt sig uden for EU-beslutninger (konstruktiv afståelse). Dette skyldtes, at den konkrete udvikling i EU på dette område var beskeden. Baggrunden var uenigheder mellem især UK og Frankrig om, hvorvidt EU skulle bruges til at udvikle en europæisk militær kapacitet.

På et møde i den franske by Saint
Malo i 1998 blev London og Paris imidlertid enige om, at EU kunne og skulle bruges som udgangspunkt for en sådan autonom europæisk militær kapacitet. Dette blev udgangspunktet for den senere udvikling i EU fra 1999, hvor konkrete EU-strukturer og et styrkekatalog blev opstillet og den første militære operation ud af fire blev påbegyndt i 2003.

Saint Malo-dynamikken fik større betydning for det danske forbehold, idet den afskar Danmark fra deltagelse i flere sammenhænge i forhold til opbygningen af ESDP'en (European Security and Defense Policy).

Det danske forsvarsforhold var i høj grad bundet op på formuleringerne $\mathrm{i}$ artikel 17 (tidligere artikel J.4.2) i Traktaten om den Europæiske Union (TEU), således at Danmark ikke deltog i vedtagelser under denne artikel uanset deres kon- 
krete indhold. I forbindelse med en regeringsredegørelse forud for det danske formandskab i efteråret 2002 blev forbeholdet imidlertid reformuleret således, at det i mindre grad var bundet til en konkret artikel i traktaten. Den konkrete anledning var for regeringen at skabe klarhed over, på hvilke områder Danmark kunne påtage sig formandshvervet.

Det præciseredes i redegørelsen, at vægten skulle ligge på de foranstaltninger, der havde konkret indvirkning på forsvarsområdet. Dette bundede i forventningen om, at mange forsvarsmæssige foranstaltninger efter Nice-traktaten ville blive truffet med henvisning til TEU artikel 14 om fælles aktioner i stedet for artikel 17, hvilket muliggjorde en vurdering af substansen i de enkelte beslutninger i lyset af forbeholdet.

Denne redegørelse var baggrunden for, at Danmark i modsætning til tidligere nu kunne deltage i EUpolitiopgaver og de øvrige civile dele af ESDP. 2001-redegørelsen var ikke politisk kontroversiel, idet der alene blev ytret tilfredshed med, at Danmark nu kunne tage del i de civile dele af ESDP.

\section{Efter Saint Malo}

Konsekvenserne for den danske holdning til ESDP'en under Saint Malo-processen har været en meget ringe grad af deltagelse på konkrete militære områder i EU, på trods af at Danmark i generelle termer har støttet processen. Danmark har således ikke tilmeldt styrker til EU's styrkekatalog, som blev etableret i 2000. Man har fra dansk side ikke deltaget i de første fire militære EU-aktioner i Makedonien og Congo i 2003, Bosnien (2004-) og Tchad (2008-). I Makedonien og Bosnien blev de danske styrker, som forud for operationen havde været en del af NATOstyrker, trukket tilbage, da operationen blev overdraget til EU, på trods af de stort set identiske opgaver som styrkerne skulle løse.

Danmark har ikke deltaget i beslutningen om oprettelsen af et EUsatellitcenter i 2001, idet man dog har bidraget til den civile del af centerets drift. København deltog heller ikke i Rådsbeslutningen om den såkaldte Athena-mekanisme i 2003, som omhandlede principperne for fælles udgifter for EU-operationer, som havde implikationer på det militære område.

Danmark deltog heller ikke den fælles aktion, som i 2004 etablerede et europæisk forsvarsagentur (EDA). Samlet er det danske forsvarsforbehold blevet anvendt i forbindelse med 12 beslutninger i perioden 1993-2005.

Jo mere generelle politiske sammenhænge der er tale om i EU (i modsætning til vedtagelse af konkrete retsakter), jo større manøvrerum ses Danmark at have inden for regeringens tolkning af forsvarsforbehol- 
det. Danmark deltager således i generelle politiske diskussioner og udformningen af dokumenter som for eksempel Den Europæiske Sikkerhedsstrategi i 2003.

Generelt har Danmark dog holdt en meget lav profil på det snævre militære område. Forsvarsministeren er til stede ved diskussioner i EU om militære spørgsmål, men deltager ikke i disse. I EU's militærkomité tager den danske repræsentant sjældent ordet og deltager ikke i afstemninger. I militærstaben har den danske officer fået tildelt opgaver, som ikke vedrører centrale militære aspekter.

Danmark har således kun i meget ringe grad deltaget i den konkrete udvikling af den militære dimension af ESDP, som er foregået med Saint Malo-processen siden 1998. Imidlertid har Danmark taget del i de civile dele af ESDP med en relativ høj profil og har således stillet flere forslag på dette område. København har stærkt støttet en tættere koordination af de militære og de civile dele af ESDP. Dansk mandskab har således taget del i alle civile operationer under ESDP hidtil med undtagelse af operationerne i Congo.

En del af baggrunden for den danske aktivitet på dette felt er utvivlsomt diplomatisk kompensation - en måde at kompensere for det manglende militære engagement $\mathrm{i}$ den øvrige ESDP.

Helt tilbage fra midten af 1990' erne har der været en fundamental spænding i den danske politik over for den europæiske forsvarsdimension. På ene side har regeringerne holdt Danmark uden for de ovenfor anførte operationer og anlagt en meget lav profil på forsvarsområdet i EU under henvisning til forbeholdet. På den anden side har regeringerne klart sagt, at man mente at forsvarsforbeholdet (ligesom de øvrige forbehold) var skadelige for Danmarks muligheder for at fremme sine synspunkter og præge sine omgivelser.

Fra midten af 1990'erne har regeringerne gjort klart, at man mente at en EU-rolle på det militære område var nyttig, og fremlagt dette synspunkt i EU. Samtidig har Danmark ikke selv kunnet deltage i den konkrete udformning af den militære dimension og i de fire operationer. Spændingen mellem, hvad Danmark kunne være med til, og hvad regeringerne ønskede at være med til, har været stigende i takt med, at EU's udvikling på ESDP-området er blevet mere substantiel siden 1998 .

\section{Svækket dansk indflydelse}

Siden Saint Malo i 1998 er den konkrete betydning af de danske forbehold altså øget i takt med, at EUsamarbejdet på forsvarsområdet er blevet mere substantielt. Danmark har ikke haft indflydelse på opbygningen af de politisk/administrative strukturer på det militære område $\mathrm{i}$ EU, som er blevet opbygget siden år 
2000, har ikke kunnet tildele styrker til styrkekataloget eller kunnet deltage i konkrete militære operationer.

København har ikke deltaget i opstillingen af en planlægningscelle eller forberedelsen af denne som et ad hoc hovedkvarter, som blev besluttet i 2003 - af nogen kaldet Saint Malo 2. Man deltager heller ikke i de kampgrupper, som er under udvikling. Danmark har ikke kunnet deltage i EU-kampgruppen bestående af styrker fra Sverige, Finland, Norge, Irland og Estland under svensk ledelse.

De danske forbehold er båret over i Reformtraktaten i form af en protokol, således at Danmark ikke deltager i de dele af traktaten, som forøger samarbejdet på det militære område (forstærket samarbejde, bistandsgaranti, store dele af forsvarsagenturet og solidaritetsklausulen, hvor de to sidstnæunte dog er blevet indført før traktaten).

Som nævnt ovenfor betyder det ikke, at Danmark ikke kan udtale sig om den udvikling som traktaten giver anledning til i generelle (forventeligt positive) termer. Når den danske regering og den del af oppositionen, som støtter reformtraktaten, mener at det er en god traktat, inkluderer det således også det, som sker på forsvarsområdet. Men der vil ikke være tale om danske fingeraftryk i forbindelse med udmøntningen af disse elementer i den nye traktat.

Et andet forhold, der svækker mu- ligheden for dansk indflydelse er det stigende antal af 'tværgående retsakter'. Der indgår både områder, som er berørt af forbeholdet, og områder, hvor det ikke er tilfældet. Her kan det blive et problem for Danmark, at de militære områder kan blive så tæt sammenvævet med civile, at forbeholdet på det militære felt de facto betyder, at man ikke kan deltage i de resterende ikke-militære dele.

Denne sammenvævning har Danmark varmt støttet. Målet om integreret krisestyring kan på grund af forsvarsforbeholdet gøre, at Danmark kan blive mindre central inden for integreret krisestyring på trods af praktiske danske forsøg på at skille tingene ad.

Udviklingen inden for ESDP, som om noget styrkes med reformtraktaten, har også bredere europapolitiske konsekvenser for Danmark. Den foreliggende udvikling bidrager i endnu højere grad til, at København kan få problemer med at finde samarbejdspartnere i et EU med 27 medlemmer, hvor indgåelse af poliske alliancer er centralt for at opnå indflydelse.

Det må dog samtidig understreges, at det på det udenrigspolitiske område fortsat vil være langt den overvejende del af det udenrigspolitiske samarbejde i EU, som ikke er knyttet til EU's forsvarsdimension. Danmark deltager således fuldt ud i langt størstedelen af de mere end 100 erklæringer, fælles aktioner og 
fælles positioner, som hvert år udsendes inden for EU's udenrigspolitik. Ej heller forhindrer forbeholdet som nævnt Danmark i at udtale sig i generelle sikkerhedspolitiske anliggender, også af betydning for ESDP'en.

Derfor er Danmark heller ikke en problematisk samarbejdspartner på langt de fleste udenrigs- og sikkerhedspolitiske spørgsmål i EU. Det vil ikke være korrekt at fremstille Danmark som generelt marginaliseret i tilblivelsen af EU's udenrigs- og sikkerhedspolitik. Men udviklingen gør det ikke nemmere for København at finde partnere.

\section{Mindre attraktiv partner?}

Hidtil har jeg behandlet konsekvenserne af den danske politik inden for EU.

Spændingen mellem en styrket ESDP og manglende muligheder inden for denne kan dog også have implikationer for dansk udenrigs- og sikkerhedspolitik på andre områder. En stærkere EU-forsvarsdimension med tætte forbindelser til NATO, OSCE og FN vil gøre Danmark til en mindre attraktiv partner i disse fora, hvis Danmark ikke kan deltage i EU på grund af forbeholdet.

Hvis EU kommer til at engagere sig i en række af de fredsst $\varnothing$ ttende operationer, som Danmark traditionelt har engageret sig i gennem FN og NATO, kan Danmark få problemer med at deltage i samarbejdet på dette område i andre organisationer. Det kan stille Danmark i en svagere situation i NATO, at det så at sige kun kan deltage på NATO-siden i operationer, hvor NATO låner kapabiliteter og aktiver til EU gennem Berlin Plus-aftalen.

Nogle alliancepartnere ser måske Danmark som en allieret, der ikke yder noget i konflikter, hvor der ofte er bred enighed om ønskeligheden af konfliktløsning, altså substansen, og hvor Danmarks position endvidere kan være vanskelig at forstå (Makedonien, Congo, Bosnien).

Man skal dog se dette problem i den større sammenhæng, hvori Danmarks NATO-deltagelse foregår. Danmarks aktive og relativt høje militære deltagelse i Kosovo og Afghanistan peger jo på en allieret, som deltager uden reservationer - i modsætning til flere af de store lande. Spørgsmålet er om ikke billedet fra Kosovo og Afghanistan, hvor Danmarks soldater deltager i første linje, vejer tungere end Danmarks holden sig uden for EU's militære operationer.

Inden for det nordiske samarbejde har forbeholdet givet anledning til nogle problemer. Danmark har siden etableringen af det nordiske militære samarbejde i NORDCAPS i 1997 haft problemer med denne styrkes forbindelse med EU. Dette har kompliceret samarbejdet, men har dog ikke umuliggjort det. Der er således i december 2007 blevet fremlagt et svensk forslag om fælles nordisk samarbejde 
på forsvarsmaterielområdet, hvori Danmark også indgår.

\section{Dansk kompensation}

Hvis militær deltagelse i internationale opgaver forstås som en vigtig del af den danske udenrigspolitiske identitet og den 'aktive internationalisme' og den 'offensive danske udenrigspolitik' (den siddende regerings term), kan forsvarsforbeholdet gøre at den militære deltagelse presses over i andre baner.

Der er imidlertid ikke tale om en automatisk kompensationsmekanisme, men netop en mekanisme som bygger på forståelsen af de militære midlers centrale rolle i dansk udenrigspolitisk identitet. En høj udenrigspolitisk profil kunne i princippet basere sig på andre end militære elementer, hvad den da også allerede i vidt omfang gør i Danmarks tilfælde i form af en (stadig) relativt og absolut høj ulandsbistand.

Det hævdes ofte, at konsekvensen af forsvarsforbeholdet har kunnet aflæses i den generelle danske udenrigspolitik. Dette har dels taget form af et stadig tæettere sikkerhedspolitisk forhold til USA efter den Kolde Krig (og især efter 2001) og dels i form af øget fokus på højintensive militære operationer.

Antagelsen bag dette er den såkaldte kompensationstese, som går ud fra, at Danmark gennem disse to elementer kompenserer for den manglende indflydelse og mulighed for aktiv deltagelse i EU. Isoleret set forekommer det plausibelt, at hvis militære midler er væsentlige i den 'offensive udenrigspolitik', og EU's udvikling ikke giver mulighed for en dansk profil på det lavintensive område, så vil dansk aktivitet skulle finde sted uden for EU med pres for stærkere indsatser som for eksempel højintensive militære operationer med USA.

Men spørgsmålet om hvor tæt på USA Danmark placerer sig, er imidlertid underlagt et mere fundamentalt valg: Hvordan Danmark ønsker at placere sig i forhold til USA under unipolariteten. Her er Danmarks atlantiske orientering grundlæggende, ligesom den er det for andre atlantisk-orienterede lande som UK, Portugal, Holland (hvor disse tre ikke har forsvarsforbehold) og Norge.

Selv uden forbehold ville Danmark formentlig også være en atlantisk-orienteret stat med noget nær den samme forståelse af det væsentlige $\mathrm{i}$ at få indflydelse gennem et godt forhold til USA. De mange referencer i officielle danske regeringssammenhænge til en historisk baseret samhørighed og fælles værdier med USA peger på, at dette er mere end blot en konsekvens af forbeholdet. Men forbeholdet trækker isoleret set i samme retning.

Om det modsatte også er tilfældet - at et Danmark uden forsvarsforbehold trækkes mod EU - er mindre klart. For nogle dele af SF og Social- 
demokratiet er det den sammenhæng der etableres. For regeringen kædes en ophævelse af forsvarsforbeholdet imidlertid ikke sammen med en svækkelse af forholdet til USA, idet man lægger vægt på et tæt samarbejde over Atlanten, sådan at man sagtens kan blæse og have mel i munden.

\section{Folkeafstemning?}

Hvorvidt man mener, at der bør være en folkeafstemning om et eller flere af de danske forbehold afhænger af, om man mener, at forbeholdene er politisk ønskelige. I bredere forstand har det at gøre med, hvordan man mener, at Danmark skal placere sig i det europæiske samarbejde, og hvilken rolle EU skal indtage i dansk udenrigs- og sikkerhedspolitik.

Men hvis man rejser spørgsmålet om, på hvilket forbeholdsområde en afstemning er mest relevant, forekommer forsvarsområdet (sammen med retsforbeholdet) at være kandidat snarere end forbeholdet over for euroen. Der blev stemt om euroforbeholdet i 2000 på et tidspunkt, hvor de europæiske valutakurser var blevet låst fast, og euroen skulle introduceres som fysisk valuta kort efter. Der har derimod ikke været afstemning om forsvarsforbeholdet (eller retsforbeholdet) i de mere end 14 år, hvor det har været i kraft. Med Saint Malo-processen fra 1998 har udviklingen af EU's forsvarsdimension fået en langt mere konkret karakter, end den havde i 1993. I den udstrækning det vurderes som rimeligt at tage stilling til forbeholdene igen ved folkeafstemning, kunne man argumentere for, at befolkningen ikke har haft mulighed for at tage stilling til den konkrete karakter af de europæiske forsvarsstrukturer og implikationerne af Danmarks fravær i disse (på samme måde som udviklingen af retsdimensionen).

Men disse overvejelser om valg af afstemningsfelt vil skulle konkurrere med politiske overvejelser over betydningen af Danmarks manglende deltagelse på de tre områder samt områdets relevans i en større sammenhæng. Forsvarsforbeholdet har en forholdsvis afgrænset udenrigspolitisk betydning, hvilket kan afskrække fra en enkeltstående debat om dette, da udenrigspolitik ofte ikke står højest på dagsordenen, når der spørges til folks politiske interesse.

Det er derfor spørgsmålet om forsvarsforbeholdet kan bære en folkeafstemning alene, eller om det skal kædes sammen med andre for at opnå tilstrækkelig folkelig interesse.

Henrik Larsen, lektor, ph.d., Jean Monnet professor, Institut for Statskundskab, Københavns Universitet. 